\title{
Pharmaciana
}

Vol.10, No.2, July 2020, Page. 175-184

ISSN: 2088 4559; e-ISSN: 24770256

DOI: $10.12928 /$ pharmaciana.v10i2.15926

\section{The relationship between NFk $\beta$-p65 and PGE2 gene expression in osteoarthritis synoviocyte cells after mesenchymal stem cell Wharton Jelly Treatment}

\author{
Vivi Sofia \\ Department of Pharmacology and Clinical Pharmacy, \\ Faculty of Pharmacy, Universitas Ahmad Dahlan \\ Jl. Prof. Dr. Soepomo, Janturan, Yogyakarta, Indonesia
}

Submitted: 26-02-2020

Reviewed: 21-04-2020

Accepted: 27-07-2020

\begin{abstract}
The genes involved in cartilage degradation in the pathogenesis of osteoarthritis (OA) are the Nuclear Factor Kappa Beta $(\mathrm{NF \kappa} \beta)$ gene, which plays a vital role in modulating cartilage damage involving activation of pro-inflammatory cytokines, including prostaglandin E2 (PGE2). This pure experimental research aimed at analyzing the relationship between the expression of $\mathrm{NFK} \beta$ genes after administration of mesenchymal stem cells in osteoarthritis synoviocytes in vitro from Wharton's Jelly (WJ-MSCs). The samples were isolated from synovial tissues of patients with osteoarthritis who underwent Total Knee Replacement (TKR) surgery and then divided into six treatment groups, each with four replicates. Groups I and II were the synoviocyte-control classes of $24 \mathrm{~h}$ and $48 \mathrm{~h}$ (synoviocytes, incubated for 24 and 48 hours respectively). Groups III and IV were control groups of 24h and 48h WJ-MSCs (mesenchymal stem cells derived from the Wharton's Jelly, incubated for 24 and 48 hours respectively). Finally, Groups V and VI were the 24-hour and 48-hour co-cultural treatment groups (synoviocyte co-culture and WJ-MSCs, Incubated, for 24 and 48 hours respectively). Using qPCR, PGE2 gene and NF NFк $\beta$ gene expressions were observed in each population. Tests showed 0.61 and 0.61 , respectively, after the administration of WJ-MSCs, the expressions of the $\mathrm{NF} \kappa \beta$-p65 and PGE2 genes in the $24 \mathrm{~h}$ classes. In the $48 \mathrm{~h}$ group, meanwhile, both numbers fell to 0.15 and 0.47 , respectively. These indicate a strong correlation between the NFk $\beta$-p65 gene and PGE2 gene expressions in OA synovial cells after the administration of MSC-WJ $(r=0.903)$.
\end{abstract}

Keywords: NFK $\beta$ gene, PGE2 gene, osteoarthritis, correlation

\footnotetext{
*Corresponding author:

Vivi Sofia

Department of Pharmacology and Clinical Pharmacy

Faculty of Pharmacy, Universitas Ahmad Dahlan

J1. Prof. Dr. Soepomo, Janturan, Yogyakarta, Indonesia

Email: vivi.sofia@pharm.uad.ac.id
} 


\section{INTRODUCTION}

Up to now, clinical progress in understanding molecular and cellular pathways Osteoarthritis (OA) has illustrated strategies to prevent (Chung et al., 2018) the harmful effects of up-regulated cytokines or other inflammatory mediators, and their related signals. At the molecular level, degenerative joint disease ends up in the imbalance between catabolic and anabolic activities, wherever the first injury response happens in joint animal tissue (Kim and Yoo, 2018). Inflammatory reaction and animal tissue degradation expressions of the many genes, like lymphokine (IL)-1 and neoplasm death issue (TNF)- $\alpha$, ar primarily regulated by NFK $\beta$. NFK $\beta$ stimulates the TNF- $\alpha$ and IL- $1 \beta$ cytokines that contribute to the inflammatory method in degenerative joint disease. The transcription of the PGE2 sequence conjointly includes NFK $\beta$. NFK $\beta$ may be a sequence that plays a key role in degenerative joint disease pathological process (Saito, 2017).

The fast development of stem cell sciences in the world of research and medicines has broadened the potential of stem cells. Stem cells have famed to achieve success in delivering lifesaving therapies to heal those affected by diseases that not result in ancient or surgical procedures of expedient. that embody chronic disorders and abnormalities, e.g. trauma and malignancy, whose prevalence is inclined to extend dramatically (Halim et al., 2010).

This experimental research was carried out in vitro using the OA patients synoviocyte tissue. It is part of a study of mesenchymal stem cells in vitro and in vivo on a greater scale. The innovation lies not only in the use of gene markers NFKB and PGE2, but also in the attempt to establish associations between the functions of both genes in OA pathogenesis, which are obtained as part of the study objectives, Is observed following in vitro administration of Mesenchymal stem cell Wharton Jelly to osteoarthritis synoviocyte cells.

\section{MATERIALS AND METHOD Tools and Materials}

The research materials consisted of synovial tissues from Prof. Dr. M.Djamil Hospital in Padang City, a total tissue isolation kit for RNA (PureLink Invitrogen USA ${ }^{\circledR}$ ), kit iScript Reverse Transcriptase cDNA synthesis (BioRad), NF $\pi \beta$-p65 primary gene (Macrogen $\left.{ }^{\circledR}\right)$, MMP-13 primary gene (Macrogen $\left.{ }^{\circledR}\right)$, HPRT1 primary gene (Macrogen $\left.{ }^{\circledR}\right)$, collagenase, deoxyribonuclease I in Dulbecco's Modified Eagle Medium (DMEM), Fetal-13 primary gene (Macrogen $\left.{ }^{\circledR}\right)$, Collagenase, Deoxyribonuclease I in Dulbecco Modified Eagle Medium (DMEM), Fetal Bovine Serum (FBS) from The Life Technologies ${ }^{\circledR}$, RT-PCR (ThermoFisher Scientific ${ }^{\circledR}$ ), NanoDrop 2000 Spechtrofotometer (ThermoFisher Scientific ${ }^{\circledR}$ ), and ThermoFisher Scientific ${ }^{\circledR}$ centrifuge. The Andalas University of Cancer and Stem Cell Deoxyribonuclease I in Dulbecco Modified Eagle Medium (DMEM), Fetal Bovine Serum (FBS) from The Life Technologies ${ }^{\circledR}$, RT-PCR (ThermoFisher Scientific ${ }^{\circledR}$ ), NanoDrop 2000 Spechtrofotometer (ThermoFisher Scientific (®), and ThermoFisher Scientific ® centrifuge. The Andalas University of Cancer and Stem Cell Study Center works for the Indonesian Institute of Medical Education and Research (IMERI), Faculty of Medicine, University of Indonesia. have procured mesenchymal stem cells from Wharton Jelly (MSC-WJ), i.e. have procured mesenchymal stem cells from Wharton Jelly (MSC-WJ)

\section{Method}

Samples were collected from a total of ten patients aged 50-70 years, male and female. $10^{5}$ cells were used for each group. (Ibrahim et al.,2015).

\section{Co-culture MSC-WJ and synoviocyte cells}

Synoviocyte cells were grown up to 50-60 per cent, then cultivated with MSC-WJ and synoviocyte cells incubated in a CO2 incubator for 24 and 48 hours (Rosengren et al., 2007). 


\section{Primer designs}

The base sequences of the primers of the NFK $\beta$ gene are according to a reference article, namely primer forward 5'-CGCATCCAGACCAACAA-3' and primer reverse 5'AGATGGGATGAGAAAGGACAGG-3'. The MMP-13 gene for the primer forward was 5'CACTTTATGCTTCCTGATGACG-3' and for the reverse primer was 5'TCCTCGGAGACTGGTAATGG-3' (Yamada et al., 2010). As a control in the Real-Time PCR examination, the HPRT1 gene was used with the primer forward 5 'CCTGGCGTCGTGATTAGTGAT-3' and the reverse primer: 5 '-CCCATCTCCTTCATCACATCTC3' (Watanabe et al.,2017).

\section{RNA isolation}

A total of five hundred mikroliter cells that had been treated with stem cells and triazole were homogenized and placed in an exceedingly $1.5 \mathrm{ml}$ PCR tube. Afterward, they were more with one hundred ul of chloroform, subjected to a homogenous incubation for five minutes, and centrifuged at $12,000 \mathrm{~g}$ for quarter-hour at $4^{\circ} \mathrm{C}$. the highest layer (supernatant) was removed to a new tube, more with $250 \mu \mathrm{L}$ of isopropranolol, and shaken (in back and forth motion), then allowed to square for ten minutes at $4{ }^{\circ} \mathrm{C}$. This mixture was then combined with five hundred five hundred of seventy five p.c grain alcohol, shaken, and centrifuged for five minutes at $4{ }^{\circ} \mathrm{C}$ with speed of $7.500 \mathrm{~g}$. The highest layer containing grain alcohol was stripped, dried for quarter-hour, then applied RNase-free water with twenty five hundred and diluted per the NanoDrop polymer concentration victimisation the BioRad manual package operational procedures, USA.

\section{PCR gradient amplification}

The SYBR Green amplification kit was used to replicate every gene. The PCR system was set as follows: predenaturation for 30 seconds at $95^{\circ} \mathrm{C}$, denaturation for 5 seconds, gradient annealing during five seconds at $55{ }^{\circ} \mathrm{C}$ (consisting of 50 cycles), and incremental melting curve from 65 to $95{ }^{\circ} \mathrm{C}$, with an rise of $0.5^{\circ} \mathrm{C}$ per five seconds.

\section{cDNA synthesis}

The total synthesis of desoxyribonucleic acid consisted of five $\mu \mathrm{g}$ total ribonucleic acid, 1x RT buffer, twenty pmol oligodT, $4 \mathrm{mM}$ dNTP, $10 \mathrm{mM}$ DTT, forty U SuperScript TMII RTase catalyst, and twenty $\mu \mathrm{LEPC}-\mathrm{H} 2 \mathrm{O}$, severally. At $52^{\circ} \mathrm{C}$ for fifty minutes the entire desoxyribonucleic acid was synthesized with the operative procedures of the BioRad, USA manual kit.

This analysis used Livak-Schmittgen's (2001) relative quantification method, or quantitative analysis using the Threshold delta or Plaffl method.

$$
\begin{array}{lll}
\Delta \mathrm{C}_{\mathrm{T} \text { experimental }} & =\mathrm{C}_{\mathrm{T} \text { target in experiments }} & -\mathrm{C}_{\mathrm{T} \text { housekeeping in experiments }} \\
\Delta \mathrm{C}_{\mathrm{T} \text { control }} & =\mathrm{C}_{\mathrm{T} \text { target of control }} & -\mathrm{C}_{\mathrm{T} \text { housekeeping of control }} \\
\Delta \Delta \mathrm{C}_{\mathrm{T}} & =\Delta \mathrm{C}_{\mathrm{T} \text { experimental }} & -\Delta \mathrm{C}_{\mathrm{T} \text { control }}
\end{array}
$$

The levels of expressions were determined using the equation Comparison of rates of gene expression $=2^{-\Delta \Delta \mathrm{CT}}$ where the gene HPRT1 as a control gene (housekeeping).

\section{Sample size}

The sample size was determined using the Federer formula (1977). The experiments used six groups, each consisting of 4 repetitions. The division of groups is as follows: 
Group I : 24h synoviocytes-control group, i.e., Synovial OA cells incubated during 24 hours

Group II : 48h synoviocytes-control group, i.e., OA synovial cells incubated during 48 hours

Group III : 24h WJ-MSCs control group, i.e., a control group consisting of mesenchymal stem cells sourced from the Wharton's Jelly and incubated during 24 hours

Group IV : 48h WJ-MSCs control group, i.e., a control group consisting of WJ-MSCs incubated during 48 hours

Group V : 24h co-culture treatment group, i.e., co-culture of OA synovial cells and WJMSCs that were incubated during 24 hours

Group VI : 48 co-culture treatment group, i.e., co-culture of OA synovial cells and WJMSCs that were incubated during 48 hours

\section{Ethical approval}

The research permit is in the process of submission to the Research Ethics Committee of the Medical Faculty, Andalas University. In the event of approval, it will receive a registration number: 550/KEP/FK/2017.

\section{Statistical analysis}

The research data and experiment results, including the NFK $\beta$ gene and PGE-2 gene expressions and the Pearson's correlation coefficients, are presented in tables and graphs. These data were processed in the statistical SPSS 22 program.

\section{RESULTS AND DISCUSSION}

\section{Expression of NFK $\beta$ and PGE2 genes}

Prior to the analysis, a preliminary test of data normality and homogeneity was performed. Among both classes, the Shapiro-Wilk normality check yielded important values of 0.05 , indicating the data were normally distributed.

The results of the descriptive analysis, i.e., skewness ratio of $<2$ in all groups, support this conclusion. Also, the Levene's test revealed that the homogeneity of variance was $0.16 \geq 0.05$, indicating that the data used in the NFK $\beta$ and PGE2 gene research have the same variant (homogeneous). After administration of WJ-MSCs, the Pearson test was performed to know the expressions of the NFK $\beta$ gene and the PGE2 gene correlation.

Table 1. Analysis of $\mathrm{NF}_{\mathrm{K}} \beta \mathrm{p} 65$ gene relative expression levels using the Livak-Schmittgen method (2001)

\begin{tabular}{|c|c|c|c|c|c|}
\hline Groups $(n=4)$ & $\begin{array}{c}\text { C }_{\text {T }} \text { average } \\
\text { NFK } \beta \\
(\bar{x} \pm \mathrm{SD})\end{array}$ & $\begin{array}{c}\text { CT }_{\text {average }} \\
\text { HPRT1 } \\
(\bar{x} \pm \mathrm{SD})\end{array}$ & $\begin{array}{c}\Delta \mathrm{C}_{\mathrm{T}}= \\
\text { NFK } \beta- \\
\text { HPRT1 }\end{array}$ & $\begin{array}{c}\Delta \Delta \mathrm{C}_{\mathrm{T}}= \\
\Delta \mathrm{C}_{\mathrm{T}} \\
\text { treatment - } \\
\Delta \mathrm{C}_{\mathrm{T}} \text { control }\end{array}$ & $2-\Delta \Delta C T$ \\
\hline 24 h synoviocytes-control & $35.72 \pm 0.32$ & $33.29 \pm 0.15$ & 2.43 & 0.00 & 1 \\
\hline 24h WJ-MSCs control & $35.64 \pm 0.24$ & $32.50 \pm 0.28$ & 3.14 & 0.71 & 0.67 \\
\hline $24 \mathrm{~h}$ co-culture treatment & $36.35 \pm 0.35$ & $33.34 \pm 0.32$ & 3.01 & 0.58 & 0.61 \\
\hline $48 \mathrm{~h}$ synoviocytes-control & $35.94 \pm 0.20$ & $33.95 \pm 0.19$ & 1.99 & 0.00 & 1 \\
\hline 48h WJ-MSCs control & $38.56 \pm 0.38$ & $33.90 \pm 0.33$ & 4.66 & 2.67 & 0.16 \\
\hline $48 \mathrm{~h}$ co-culture treatment & $37.09 \pm 0,14$ & $32.41 \pm 0.28$ & 4.68 & 2.69 & 0.15 \\
\hline
\end{tabular}


Table 2. Analysis of $\mathrm{PGE}_{2}$ gene relative expression levels using the Livak-Schmittgen method

\begin{tabular}{|c|c|c|c|c|c|}
\hline Groups & $\begin{array}{c}\text { C } \mathrm{T} \text { average } \\
\text { PGE2 } \\
(\bar{x} \pm \mathrm{SD})\end{array}$ & $\begin{array}{c}\text { C }_{\text {T }} \text { average } \\
\text { HPRT1 } \\
(\bar{x} \pm \mathrm{SD})\end{array}$ & $\begin{array}{c}\Delta C_{T}= \\
\text { PGE2- } \\
\text { HPRT1 }\end{array}$ & $\begin{array}{c}\Delta \Delta \mathrm{C}_{\mathrm{T}}= \\
\Delta \mathrm{C}_{\mathrm{T}} \\
\text { treatment - } \\
\Delta \mathrm{C}_{\mathrm{T}} \text { control }\end{array}$ & $\underset{\Delta \Delta C T}{2^{-}}$ \\
\hline 24h synoviocytes-control & $35.05 \pm 0.22$ & $33.29 \pm 0.19$ & 1.76 & 0.00 & 1 \\
\hline 24h WJ-MSCs control & $34.72 \pm 0.16$ & $32.50 \pm 0.28$ & 2.22 & 0.46 & 0.73 \\
\hline $24 \mathrm{~h}$ co-culture treatment & $35.82 \pm 0.23$ & $33.34 \pm 0.09$ & 2.48 & 0.72 & 0.61 \\
\hline 48h synoviocytes-control & $34.87 \pm 0.33$ & $33.95 \pm 0.14$ & 0.92 & 0.00 & 1 \\
\hline 48h WJ-MSCs control & $35.52 \pm 0.25$ & $33.90 \pm 0.32$ & 1.62 & 0.70 & 0.62 \\
\hline $48 \mathrm{~h}$ co-culture treatment & $34.44 \pm 0.16$ & $32.41 \pm 0.27$ & 2.03 & 1.11 & 0.47 \\
\hline
\end{tabular}

Tables 1 and table 2 show that the $48 \mathrm{~h}$ synoviocytes-control and $48 \mathrm{~h}$ co-culture groups

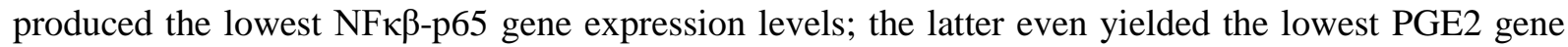

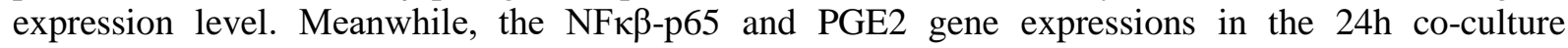
treatment group (co-culture of OA synoviocytes and WJ-MSCs) were higher than its $48 \mathrm{~h}$ counterpart, but lower than the 24h WJ-MSCs control group.

\section{Correlation between NFK $\beta$ gene expression and PGE2 gene expression}

Table 3. Correlation between the expressions of NFKß gene and PGE2 gene (Pearson's correlation test)

\begin{tabular}{|c|c|c|c|c|}
\hline Variables & NFк及-p65 & PGE2 & $\mathbf{r}^{2}$ & $p$ \\
\hline $\begin{array}{c}\text { NFк } \beta-p 65 \\
\text { PGE2 }\end{array}$ & $\begin{array}{c}1 \\
0.903\end{array}$ & $\begin{array}{c}0.903 \\
1\end{array}$ & 0.909 & 0.01 \\
\hline
\end{tabular}

Table 3 provides a strong correlation, which is apparent from the analogous rates and patterns, between the populations of NF $\beta$ genes and PGE 2 genes. Based on the correlation coefficients of the Pearson, it was observed that NFK $\beta$ gene expression is closely correlated with PGE2 gene expression, with $r=0.903$ (in the range of $0.70-0.99$ ) and $p=0.01$. Likewise, Figure. 1 And Figure. 2 indicate that the NFK $\beta$ gene is expressed in lower the PGE2 gene expression.

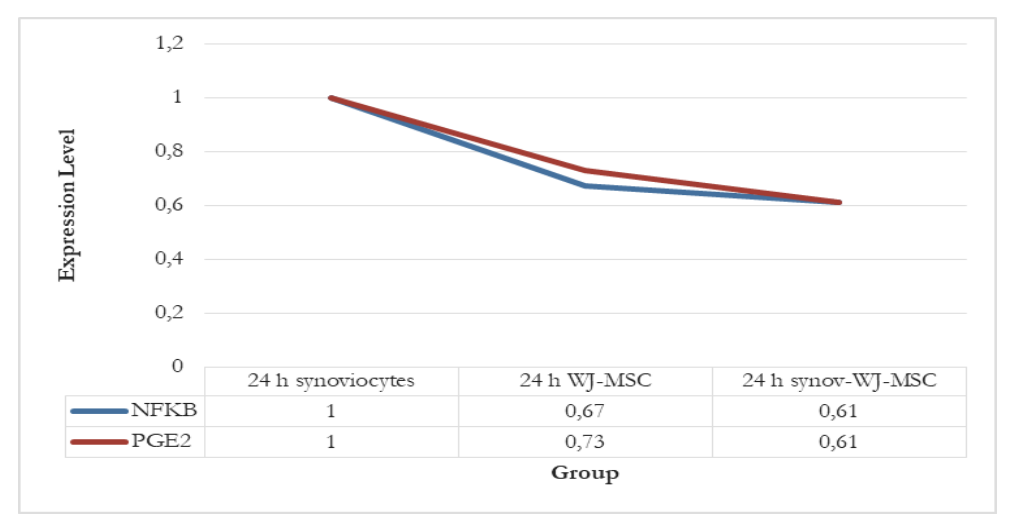

Figure 1. The correlation of NFKßp65 and PGE2 gene expressions during 24 hours of incubation 


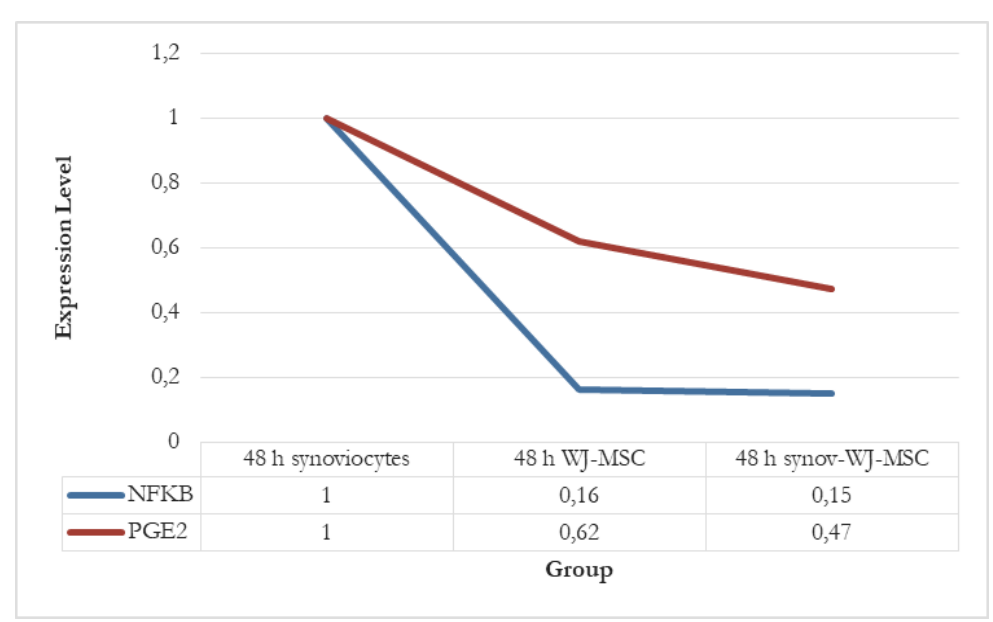

Figure 2. The correlation of NFK $\beta$ 65 and PGE2 gene expressions during 48 hours of incubation

During the inflammatory process of OA pathogenesis, a widespread wide variety of proinflammatory mediators, e.g., nitric oxides (NO) and PGE2, are produced by using the inducible Nitric Oxide Synthase (iNOS) and cyclooxygenase-2 (COX-2). COX-2 is induced via pro-inflammatory stimulation, then COX-2 is authorised as an isoform accountable for the production of prostaglandins in various inflammatory models. Regulation of the PGE2 gene is very excessive in diseases such as rheumatoid arthritis, osteoarthritis and carcinoma.

High COX2 expression and PGE2 release play a major role in the initiation and development of cancer inflammation (Zhang et al., 2019). PGE2 intervenes the flagging pathway to expand NFkB actuation, in which COX-2 can advance NFкB phosphorylation. The subsequent cellular reaction culminates in the activation of various transcription factors, with a prominent role being played by $\mathrm{NF \kappa B}$. This transcription factor contributes to several strong pro-inflammatory mediators, including cytokines and chemokines that can inflict damage to local tissue. PGE2 genes involved in cartilage damage caused by OA are also dependent on the activity of NFKB (Lawson et al., 2013).

The results confirmed a advantageous $\mathrm{NFk} \beta$ relationship between NFk $\beta$ gene and PGE2 gene expressions, in which low NFK $\beta$ gene expression stages coincided with low PGE2 gene expression levels. This nice correlation happens in synoviocytes within the synovium in the pathophysiology of OA. Various research have demonstrated that the expression of countless pro-inflammatory cytokine genes, including Tumor Necrosis Factor-alpha (TNF- $\alpha$ ), Interleukin (IL)-1 $\beta$, IL-6, and PGE-2, is associated with $\mathrm{NFk} \beta$ activation. NFk $\beta$ is one of the most important transcription elements in regulating a variety of cellular genes concerned in the inflammatory response of the acute immune section and the method of cellphone survival. According to (Megias et al., 2009), NFk $\beta$ is the primary regulator of the expression of pro-inflammatory genes.

The positive correlation is consistent with what various prior pupils have found. For instance, (Prosperi et al., 2012) are proposing that NFk $\beta f$ lagging, which is a middle man or woman of provocative procedures, is additionally working as a controller and integrator with vitality digestion. It was explained that the NFk $\beta$-p38 MAPK pathway is an essential component of cell transduction signals, especially in the regulation of genes involved in the inflammatory process, such as COX-2 and PGE-2 gene expressions (Tornatore et al., 2012). Macrophages are brought on by the involvement of micro organism, viruses, or external apprehensive stimulations. Lipopolysaccharide (LPS), an endotoxin formed by gram-negative bacteria, can set off macrophages that in impact trigger signalling, such as the NF-kB pathway and the Protein Kinase pathway of mitogen activation. 
This signalling system facilitates the secretion of pro-inflammatory cytokines, such as the tumor necrosis factor ( TNF) $-\alpha$, interleukin (IL) $-1 \beta$, and IL-6, and stimulates the release of inflammatory response elements such as NO and PGE2 (Luan et al., 2014). (Sun et al., 2009) additionally suggested that MTT-III-dep activates the development of PGE-2 and COX-2 expression via NFk $\beta$ in murine macrophages.

NFK $\beta$ inhibition can inhibit the expression of inflammatory elements and pro-inflammatory cytokines. Thus, therapeutic strategies that also avoid inflammatory ailments want to be developed by using studying compounds that inhibit iNOS and COX-2, control the expression of NO and PGE2, and inhibit the secretion of pro-inflammatory cytokines such as TNF- $\alpha$, IL- $1 \beta$ and IL-6 (Chung et al., 2018).

According (Signaling and Kopitar-jerala, 2015), expressions of iNOS and COX-2 in glial cells reportedly increase in inflammatory conditions, main to the extended synthesis of NO and PGE2. Such rules of NO and PGE2 production in the course of neuroinflammation performs a vital role in the law of inflammatory balance. NFk $\beta$ is a key transcription factor that increases the expression of proinflammatory enzymes and cytokines only if it has migrated to the nucleus. In un-activated cells, NFk $\beta$ is typically placed in the cytoplasm in association with $\operatorname{I\kappa B} \alpha$, which suppresses the activation signal and prevents translocation into the nucleus. When I $\mathrm{K} \mathrm{B} \alpha$ is phosphorylated and degraded-a precursor of the activation of NF- $\kappa B, N F k \beta i$ is remoted and translocated to the nucleus (Signaling and Kopitar-jerala, 2015).

The pathogenesis of osteoarthritis ought to be maintained in stability with the regulatory mechanism of complicated homeostasis; otherwise, mobile ailment or harm can occur. Activation of the important transcription thing NFk $\beta$ controls the expression of many genes that encode cytokines, chemokines, enzymes, and adhesion molecules involved in the synthesis of mediators from inflammatory reactions. In the cytosol, NFk $\beta$ is current in an inactive nation that types complexes with the IKB protein, and its activation occurs via induction of phosphorylation, which mediates proteasomal degradation of IкB. Suppression of $N F k \beta$ activation has been linked to anti-inflammatory activity. IL-1 $\beta$-induced NFk $\beta$ will inhibit COX-2 expression and PGE2 production. The effects of this study can be used as new therapeutic goals for OA via inhibiting pro-inflammatory cytokines which play an vital function in the cartilage degradation cycle.

There has been a developing variety of studies focusing on the physiology and pathophysiology of inflammation because many disorder morbidities are now realized as the product of inflammatory strategies involving seasoned and anti-inflammatory mediators (Rasheed et al., 2016).

(Guillot et al., 2019) found that inhibition of the NFkßand PGE-2 pathways can purpose a minimize in tiers of pro-inflammatory cytokines like IL-6, IL-1 Beta, and VEGF in the synovial membrane of human knee joints suffering from OA; also, the NFkB and PGE2 pathways are shown to be interrelated. The NFk $\beta$ p65 gene, which is one of the NFk $\beta$ families, is worried in the expression of numerous genes which make a contribution to the inflammatory response in the course of the inflammatory process.

Pro-inflammatory cytokines and chemokines stimulate the $\mathrm{NF \kappa} \beta$ transcription process. Activation of $\mathrm{NFk} \beta$ will trigger gene expression that reasons harm to articular joints, ensuing in osteoarthritis. In fact, NFk $\beta$ regulates the expression of more than one adaptive genes, such as Major Complex Histocompatibility (MHC), and genes that exceedingly modify apoptosis regulation. (A.Krum et al., 2010). Also, NFk $\beta$ is necessary to modulate immune response (Tornatore et al., 2012).

During the inflammatory process, the PGE2 gene is accountable for the inflammatory response to the pathogenesis of osteoarthritis. Its activation includes the function of NFK $\beta$ as a cytokine that regulates the occurrence of inflammatory responses. NFK $\beta$ activation can also activate gene expression that reasons damage to articular joints and, eventually, osteoarthritis (Biology et al., 2013). 
Mesenchymal stem cells remoted from the Wharton's Jelly (WJ-MSCs) can reduce the expression level of the NFKB-p65 gene as a cytokine regulating the system of transcription of proinflammatory genes. Based on the interconnection between NFKB-p65 and PGE2 proven in this research, this technique is most in all likelihood to have an effect on the PGE2 gene expression, which in turn can improve the prevalence of injury to synovial tissue in OA. This effect seems due to the fact PGE2, a pro-inflammatory cytokine, plays a giant section in inflicting damages to the matrix of cartilage in joints. The results of this study provide a reference for the use of stem cells, specifically WJ-MSCs, as promising osteoarthritis therapy in the future.

\section{CONCLUSION}

There is a strong correlation between the expressions of NFK $\beta$ gene and PGE2 gene in osteoarthritis synoviocytes after the administration of Mesenchymal stem cells isolated from Jelly Wharton's.

\section{ACKNOWLEDGMENTS}

We would like to thank the Andalas Cancer Treatment Center and Stem Cell (ACRC), Andalas University, and the Indonesian Medical Education and Research Institute (IMERI), Faculty of Medicine, University of Indonesia for providing the synovial tissues. Their appreciation also applies to the University of Ahmad Dahlan for financially funding the work and to Dr Rizki Rahmadian, Sp. OT $(\mathrm{K}), \mathrm{M}$. Kes to the assistance in obtaining synovial tissue samples.

\section{REFERENCES}

A.Krum, S., Chang, J., Miranda-Carboni, G., \& Cun-Yu Wang. (2010). Novel functions for NF $\kappa$ B : inhibition of bone formation. Nat Rev Rheumatol, 6(10), 607-611. https://doi.org/10.1038/nrrheum.2010.133.Novel.

Biology, C., Rigoglou, S., \& Papavassiliou, A. G. (2013). The International Journal of Biochemistry The NF- $\square$ B signalling pathway in osteoarthritis. International Journal of Biochemistry and Cell Biology, 45(11), 2580-2584. https://doi.org/10.1016/j.biocel.2013.08.018.

Chung, Y. C., Park, S.-M., Kim, Ji. H., Lee, G. S., Lee, J. N., \& Hyun, C.-G. (2018). Antiinflammatory effect of pratol in LPS-simulated RAW 264.7 cell via NF-kB signaling pathways. Natural Product Communications, 13(5), 547-550. https://doi.org/10.1177/1934578X1801300509.

Guillot, X., Tordi, N., Laheurte, C., Pazart, L., Prati, C., Saas, P., \& Wendling, D. (2019). Local ice cryotherapy decreases synovial interleukin 6 , interleukin $1 \beta$, vascular endothelial growth factor, prostaglandin-E2, and nuclear factor kappa B p65 in human knee arthritis: A controlled study. Arthritis Research and Therapy, 21(1), 1-11. https://doi.org/10.1186/s13075-019-1965-0.

Halim, D., Murti, H., Sandra, F., \& Arief Boediono. (2010). Steam Cell: Dasar Teori dan Aplikasi Klinis. Erlangga.

Ibrahim, A. M., Elgharabawi, N. M., Makhlouf, M. M., \& Ibrahim, O. Y. (2015). Chondrogenic Differentiation of Human Umbilical Cord Blood-Derived Mesenchymal Stem Cells In Vitro. 675(June), 667-675. https://doi.org/10.1002/jemt.22520.

Kim, J., \& Yoo, J. J. (2018). Therapeutics in Osteoarthritis Based on an Understanding of Its Molecular Pathogenesis. https://doi.org/10.3390/ijms19030674.

Lawson, M. A., Parrott, J. M., Mccusker, R. H., Dantzer, R., Kelley, K. W., \& Connor, J. C. O. (2013). Intracerebroventricular administration of lipopolysaccharide induces indoleamine-2 , 3-. Journal of Neuroinflammation, 10(1), 1-9. https://doi.org/10.1186/1742-2094-10-87.

Luan, H., Zhang, Q., Wang, L., Wang, C., Zhang, M., Xu, X., Zhou, H., Li, X., Xu, Q., He, F., Yuan, J., \& Lv, Y. (2014). OM85-BV induced the productions of IL-1 $\beta$, IL-6, and TNF- $\alpha$ via TLR4and TLR2-Mediated ERK1/2/NFk $\beta$ Pathway in RAW264.7 Cells. Journal of Interferon and Cytokine Research, 34(7), 526-536. https://doi.org/10.1089/jir.2013.0077. 
Megias, J., Guillen, M. I., Clerigues, V., Rojo, A. I., Antonio Cuadrado, Castejon, M. A., Gomar, F., \& Alcaraz, M. J. (2009). Heme oxygenase-1 induction modulates microsomal prostaglandin $\mathrm{E}$ synthase-1 expression and prostaglandin E 2 production in osteoarthritic chondrocytes. Biochemical Pharmacology, 77, 1806-1813. https://doi.org/10.1016/j.bcp.2009.03.009.

Prosperi, M. C. F., Fabbiani, M., Fanti, I., Zaccarelli, M., Colafigli, M., Mondi, A., Avino, A. D., Borghetti, A., Cauda, R., \& Giambenedetto, S. Di. (2012). Predictors of first-line antiretroviral therapy discontinuation due to drug-related adverse events in HIV-infected patients: a retrospective cohort study. BMC Infectious Disease.

Rasheed, N., Alghasham, A., \& Rasheed, Z. (2016). Lactoferrin from Camelus dromedarius Inhibits Nuclear Transcription Factor - kappa B Activation, Cyclooxygenase - 2 Expression and Prostaglandin E2 Production in Stimulated Human Chondrocytes. 135-141. https://doi.org/10.4103/0974-8490.175612.

Rosengren, S., Boyle, D. L., \& Firestein, G. S. (2007). Acquisition, Culture, and Phenotyping of Synovial Fibroblasts. 135, 365-375.

Saito, T. (2017). Molecular mechanisms underlying osteoarthritis development : Notch and NF- $\kappa$ B. 1-7. https://doi.org/10.1186/s13075-017-1296-y

Signaling, N. B., \& Kopitar-jerala, N. (2015). Innate Immune Response in Brain ,. 8(December), 1-9. https://doi.org/10.3389/fnmol.2015.00073.

Sun, J., Ramnath, R. D., Tamizhselvi, R., \& Bhatia, M. (2009). Role of protein kinase C and phosphoinositide 3-kinase-Akt in substance P-induced proinflammatory pathways in mouse macrophages. The FASEB Journal, 23(4), 997-1010. https://doi.org/10.1096/fj.08-121756.

Tornatore, L., Thotakura, A. K., Bennett, J., \& Moretti, M. (2012). The nuclear factor kappa B signaling pathway: integrating metabolism with inflammation. Trends in Cell Biology, 22(11), 557-566. https://doi.org/10.1016/j.tcb.2012.08.001.

Watanabe, H., Ishii, H., Takahashi, K., \& Takai, S. (2017). Suitable reference gene selection for gene expression studies in knee osteoarthritis synovium using quantitative PCR analysis. Connective Tissue Research, 00(00), 1-13. https://doi.org/10.1080/03008207.2017.1391234.

Yamada, T., Oshima, T., Yoshihara, K., Tamura, S., Kanazawa, A., Inagaki, D., Yamamoto, N., Sato, T., Fujii, S., Numata, K., Kunisaki, C., Shiozawa, M., Morinaga, S., Akaike, M., Rino, Y., Tanaka, K., Masuda, M., \& Imada, T. (2010). Overexpression of MMP-13 gene in colorectal cancer with liver metastasis. Anticancer Research, 30(7), 2693-2699.

Zhang, X., Yan, K., Deng, L., Liang, J., Liang, H., Feng, D., \& Ling, B. (2019). Cyclooxygenase 2 Promotes Proliferation and Invasion in Ovarian Cancer Cells via the PGE2 / NF- $k$ B Pathway. 28, 1-13. https://doi.org/10.1177/0963689719890597. 
